\title{
Human Security and Political Violence in the Middle East: Views From Security-Development Nexus Perspective
}

\author{
Hisae Nakanishi \\ Global Studies Faculty \\ Doshisha University \\ Kyoto, Japan \\ hisaen@mug.biglobe.ne.jp
}

\begin{abstract}
The objective of this paper is to examine how the Civil War in Syria has continued despite immense global impacts. The debate on security-development nexus as well as Human Security perspective are utilized to analyze the protracted nature of the conflict. Two paradigms of "Development as Violence Reduction" and "A Violence Called Development" have shaped the analysis. This study found that neoliberal approach has some limitations to explain the prolonged conflict. The other paradigm of "A violence called development" can better address the regionally structured problems of political, social and economic development in the Middle East that influenced Syrian situations. Inclusive society is a key as SDG 16 emphasizes for human security of the marginalized both in conflict zones and even in democracies. So-called Vernacular Security perspective is also useful to project the everyday reality of people's insecurity. Balance should be made between institutional building approach and grass-root perspective to search for new alternatives.
\end{abstract}

Keywords- human security, poltiical violence, securitydevelopment nexus, protracted conflict, Syria

\section{INTRODUCTION}

It is more than the two decades since the concept of Human Security first emerged. In the age of the existence of global north and global south rather than the binary perspective of the developed and developed worlds, how to incorporate Human Security into the discussion of what development means for what people is much significant. The objective of my paper is to shed light on developmentsecurity nexus in the on-going Middle East crisis, the Civil War in Syria in particular.

Both the concept of Human Security and Vernacular Security are also employed to address as significant perspectives to explain problematic and complex relationships of development and security as well as development and peace at large. No other period than today has faced a series of tragic conflicts in the Middle East. As the ongoing conflicts in Iraq, Syria and Yemen in particular convinced us the vital need of ceasefire and searching for regional stability and peace.

The incessant conflicts in the Middle East started since the US invasion in Iraq, and the so-called Arab spring further generated a global refugee crisis. Adjacent states of Iraq and Syria such as Jordan, Turkey and Lebanon have been particularly affected. Those host countries of the refugees have been severely affected to host them as well as to deliver socioeconomic services to their own citizens. The tipping point seems to be near. How much more these host countries can embrace the influx of the vulnerable is a question. It goes without saying that Syria's civil war caused a so-called refugee crisis in Europe. A question is why Syria's civil war has continued till today?

\section{SECURITY-DEVELOPMENT NEXUS AND THE MIDDLE EAST CRISIS}

The security-development nexus was much debated in the post-cold war period. Whether peace is the precondition for development or the vice-versa has been a contested question. As peace is a broad concept and hard to define, this study deals with the security -development nexus in the context of how to achieve SDG16, that is "promote peaceful and inclusive societies for sustainable development, provide access to just for all and build effective, accountable and inclusive institutions at all levels." Table 1 illustrated below indicates two paradigms of thought on the securitydevelopment nexus that emerged in the last three decades among academicians, policymakers, and development practitioners [1].

TABLE I. THE DEVELOPMENT-SECURITY NEXUS AND ITS RELATION TO VIOLENCE AND WAR

\begin{tabular}{|c|c|}
\hline $\begin{array}{c}\text { Development as violence } \\
\text { prevention=Neoliberal perspective }\end{array}$ & A violence called development \\
\hline Conflict is development in reverse & $\begin{array}{c}\text { Conflict interconnects with capital } \\
\text { accumulation. }\end{array}$ \\
\hline $\begin{array}{c}\text { Violence is driven primarily by economic } \\
\text { incentives }\end{array}$ & $\begin{array}{c}\text { Violence is structural and linked to } \\
\text { inequality }\end{array}$ \\
\hline $\begin{array}{c}\text { War economies distort formal economies } \\
\text { The developmentisation of security } \\
\text { insecurity and violent conflict }\end{array}$ & The securitization of development \\
\hline $\begin{array}{c}\text { National security and public order are } \\
\text { preconditions for development }\end{array}$ & $\begin{array}{c}\text { State is a source of maldevelopment } \\
\text { grip of military, political and } \\
\text { economic elites }\end{array}$ \\
\hline $\begin{array}{c}\text { Stabilisation and statebuilding } \\
\text { politics }\end{array}$ \\
\hline $\begin{array}{c}\text { Globalization encourages both } \\
\text { development and security }\end{array}$ & $\begin{array}{c}\text { Subaltern resistance and unruly } \\
\text { Globalization has a backlash; } \\
\text { including networked, asymmetric } \\
\text { wars }\end{array}$ \\
\hline $\begin{array}{c}\text { Good governance promotes effectiveness } \\
\text { in economic development. }\end{array}$ & $\begin{array}{c}\text { Government is well connected with } \\
\text { global economic oligarchy. }\end{array}$ \\
\hline
\end{tabular}


The following findings were the result of the applying of selected elements in this table for the reasons Syria's conflict became protracted. First is the problem with Syria's authoritarian governance, not with that it falls in the category of fragile state. Second is the problem that "national security consolidates the grip of military, political and economic elites." Third lies in the fact that conflict interconnects with capital accumulation" in case of the Middle East in general. Tribal and clan politics has exacerbated the monopoly of state wealth that has made national security under the control of the royal families. Fourth is that the presence of external actors intervene the conflict. There are so many external players as well as regional players. A striking point here is that not all players are involved for the sake of economic gains.

Thus, the above-mentioned analysis demonstrates neoliberal oriented approach, can not explain much about the continuation of Syria's conflicts. The other approach, "A Violence called development" approach seems to provide a better framework for the analysis of why Syria's conflicts continues. Above all, the lack of accountable and inclusive institutions is a dominant factor that creates a vicious circle of state repression and political and social resistance that generates insurgent groups.

\section{HUMAN SECURITY AND VERNACULAR SECURITY}

Human security is generally defined as "protecting the vital core of all human lives in ways that enhance human fulfilment, protecting vital freedoms - fundamental to human existence and development." A question is who protects people's security? Under extreme life threat circumstances, some people resort their safety to terrorists and warlords. The so-called Vernacular Security perspective can address such a reality: the day-to-day reality on the ground. VS is also closely linked with an individual's entitlement to protect one's ontological risks and to pursue well-being. Strength of VS as a perspective to capture the reality of those who are under siege is to be able to address actual situations and conditions of the marginalized people: women, religious and ethnic minorities and those who are impoverished. In this regard, it provides a more inclusive perspective.

Neoliberal approach of "Development as violence reduction" appears to have some limitation to explain why Syrian conflicts continues. "A violence called development" can better explain the reasons. "Development" can be a violent for some people, often the marginalized. Wealth making or economic development does not necessarily pave the way for well-being of people. Thus, neoliberal practices embedded in development discourse and conflict mitigation approaches should be more problematized to search for alternative paradigms.

\section{REFERENCES}

[1] J. Luckham, Robin, "Whose Violence, Whose Security? Can Violence Reduction and Security Work for Poor, Excluded and Vulnerable People?” (Peacebuilding 2017: 5-2), p. 99-117. 